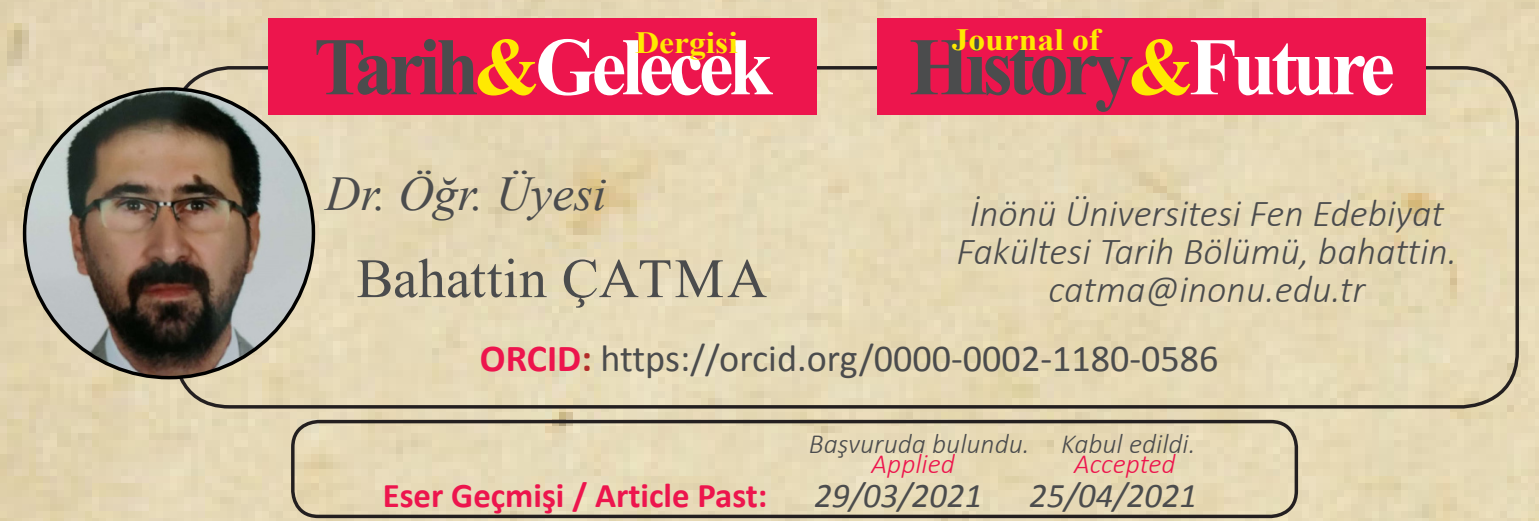

Araştırma Makalesi

DOI: http://dx.doi.org/10.21551/jhf.905224

Research Paper

Indexed by

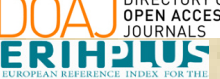

A Redemic
Resource
Index

R] $\mathbf{I} \mathbf{S} \mathbf{M}$

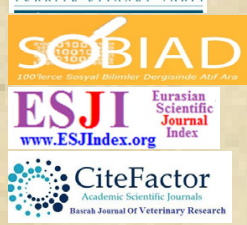

ideal

Orjinal Makale / Orginal Paper

\title{
Abdurrahman Âdil (Eren)'in Osmanlı Matbûat Âlemine Dair Hâtıraları
}

\author{
Abdurrahman Âdil Eren's Memoirs Regarding the Universe of \\ the Ottoman Press
}

\section{$\ddot{\mathbf{O z}}$}

Tarih araştırmalarında hatırat türü eserler kaynak niteliği taşıyor olmaları bakımından önemli yere sahiptirler. Söz konusu Osmanlı Devleti’nin son dönemi olduğunda bu türün önemi araştırmalar açısından daha da bir değer kazanmaktadır. Özellikle II. Meşrutiyet'in ilanını müteakip dönemlerde hatırat türü eserlerin sayısında önemli oranda artışın olması bu döneme dair araştırmalarda bu eserleri birincil kaynak olarak değerlendirmeyi elzem kılmaktadır. Bu dönem içerisinde muhtelif gerekçelerle müstakil eser halinde kaleme alınan hatıraların büyük bir kısmını son yıllarda ayniyle latinize edilerek ve sadeleştirme yoluna gidilerek neşredildiği görülmektedir. Bu müstakil eserlerin yanı sıra çeşitli gazete ve mecmualarda daha özel birtakım alanlarda gerek seyahatler neticesinde gerekse muhtelif mecralardaki tanıklıklar üzerinden tefrika şeklinde neşredilen ve hatıraları ihtiva eden metinler de vardır. Çalışmada, Abdurrahman Âdil (Eren)'in tefrika şeklinde neşredilen ve Osmanlı matbuât âlemine dair hatıralardan müteşekkil "Matbu'ât-1 Osmâniye Hâtıraları" başlığıyla İkdâm gazetesinde yayınladığı hatıraları transkribe edilmiştir.

Anahtar Kelimeler: Abdurrahman Âdil (Eren), Osmanlı Basını, Hatırat Türü Eserler

\section{Abstract}

In historical studies, memoir type publications have an important place in terms of being a source. When it comes to the last period of Ottoman Empire, the importance of this species gains more value in terms of research. Especially after the proclamation of the 2nd Constitutional, the significant increase in the number of memoir type publications makes it important to consider memoirs as primary sources in researches of this period. During this period, it is seen that most of the memoirs written as seperate works for various reasons have been published in recent years by latinizing and simplifying them. In addition to this individual works, there are also texts that contain memoirs, published as a series of articles in various

ATIF: ÇATMA Bahattin, "Abdurrahman Âdil (Eren)'in Osmanlı Matbûat Âlemine Dair Hâtıraları", Tarih ve Gelecek Dergisi, 7/2 (Haziran 2021), s. (636-654) 
newspapers and magazines, both as a result of travels and through testimonies in various fields. In this study, the memoirs of Abdurrahman Adil (Eren) published in the form of a series of articles and published in the newspaper Ikdam under the heading "Matbu'ât-1 Osmâniye Hâtıraları" consisting of his memories about the Ottoman press world were transcribed.

Keywords: Abdurrahman Âdil (Eren), The Ottoman Press, Memoir type publications

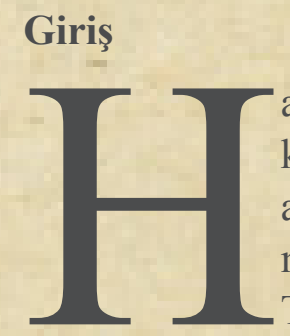

atırat ihtiva eden eserlerin batı ve doğu toplumlarındaki varlığı eski zamanlara kadar götürülebilecek mahiyettedir. Gaius Iulius Caesar'ın "Gallia Savaşı"1 adlı eseri, Gazi Zahüriddin Muhammed Babur'un hatıratı², Göktürk Kitabeleri muhtevası itibariyle bu tür eserlere örnek olarak gösterilebilir. Her ne kadar Türk-İslam geleneği içerisinde hatırat türü eserlerin varlığı muhtevalarındaki benzerlik dolayısıyla var olsa da "hatırat", bir türü adlandırır kavram olarak XX. yüzyılın başları itibariyle Osmanlı literatürüne girmiştir. Şemsettin Sami' nin Kamûs-i Türkî’ sinde hatırat kelimesine edebî bir tür manası verilmezken, 1902 tarihli Lugat-ı Nâcî'nin 1318 (1902) basımında hâtıra kelimesinin karşısında "hatırda kalmış olan hususi keyfiyet, cem 'i hâtırat; bunlara dair yazılan eserlere de hâtırat denilir” izahıyla bir tür olarak Osmanlı literatüründe yer almaya başladığı görülmektedir. Bunun yanı sıra adlandırmanın batılılaşmanın bir tezahürü olarak Fransızcadan mülhem olduğu ifade edilmektedir. ${ }^{3}$ Nitekim XX. yüzyılın ilk çeyreği itibariyle sayıca çok fazla eserin neşredilmeye başlanmış olmasının ve içerdikleri bilgilerin araştırmalar açısından kıymetinin daha bir önem kazanması bu eserlerin müstakil bir tür şeklinde değerlendirilmesini gerekli kılmıştır.

Hatırat türü eserler ya da kaynakların tarihçilik açısından oldukça önem arz ettiği malumdur. Bunun yanı sıra hatırat türü eserler "müşahede edenin hadiseleri anlayışı, istidadına ve medeni seviyesine göre türlü türlü olduğundan"” ciddi tahkik gerektiren eserlerdir. Hatırat türü eserlerin öznelliği ile alakalı Kütükoğlu da benzer bir değerlendirmede bulunmaktadır: "Hatıraların da tam bir objektiflik içinde yazılması mümkün olmayıp daima hisler ve şahsi görüşler ön plânda tutularak kaleme alınacaklarından, diğer eserlerle karşılaştırılmadan, yani tenkidi yapılmadan kullanılmaması gerekmektedir. ". 5 Söz konusu Osmanlı son dönemi olduğunda hatırat türü eserlerin kıymeti tarihçilik açısından daha da artmaktadır. Bunun bu şekilde olmasında II. Meşrutiyet öncesi ve

1 Gaius Iulius Caesar’ın “Gallia Savaşı” adlı eseri kendisinin M.Ö. 58-51 yılları aralığında yaptı̆̆ı Gallia Valiliği esnasında dahil olduğu savaşları anlattığı 7 kitaptan müteşekkil bir eserdir. Esere M.Ö. 43 yılında 8. bir kitap Aulus Hirtius tarafından ilave edilmiştir. Kitabın muhtelif baskıları bulunmaktadır. Gaius Iulius Caesar, Gallia Savaşı, Çev. Furkan Akderin, Alfa Yayınları, İstanbul 2006.

2 Eser Babur'un Fergama'da tahta çıktığı on iki yaşında iken başlayan ve ölümünden bir yıl öncesi döneme kadar geçen hükümranlık yaptığı zaman zarfını ihtiva eder mahiyettedir. Eseri kıymetli kılan hususların başında bir hükümdar tarafından kaleme alınmış olması ve bu yönüyle iyi bir otobiyografi niteliği taşımasıdır. Eserin ilk kısımları bir hatıra formu taşıyorken ilerleyen bölümlerinin günlük şeklinde olduğu görülmektedir. Gazi Zahüriddin Muhammed Babur, Vekayi- Babur'un Hâtıratı I-II, Çev. Reşir Rahmeti Arat, Türk Tarih Kurumu Basımevi, Ankara 1987.

3 Orhan Okay, "Hâtırat", TDV İslâm Ansiklopedisi, 16, İstanbul 1997, s. 445-449.

$4 \quad$ Zeki Velidi Togan, Tarihte Usul, Enderun Kitabevi, İstanbul 1985 s. 36.

5 Mübühat Kütükoğlu, Tarih Araştırmalarında Usul, Elif Kitabevi, İstanbul 2007 s. 25. 
sonrası dönemi ihtiva eden zaman aralığında bu türden eserlerin oldukça fazla miktarda neşredilmiş olması dolayısıyla önemli bir kaynak olma hüviyetine erişmesi gelmektedir. Tabi bu noktada hatırat eserlerinin yazılma gerekçelerini dikkate almak, eserin dolayısıyla eserde anlatılanların gerçekle olan irtibatını kavramakta önemli ipuçları vermektedir. Birinci, son dönem Osmanlı entelektüel hayatında görülen hatırat türü kaynakların genel anlamda II. Abdülhamid döneminde, devletin önemli kademelerinde bulunan isimlerin, bu döneme ait meselelerde masumiyetlerini ispat etmek gayesi güttüklerini belirtip bunların çabucak ya da sonradan yazılmış eserler olduğunu ifade etmektedir. Bunlara ilave yazılma maksadı farklılıklar gösteren hatırat eserleri de mevcuttur. Genel anlamda bu eserler gerek muhtevaları gerekse muharrirlerinin meslekleri dikkate alınarak belirli tasniflere tabi tutulmaktadırlar. ${ }^{6}$ Tasniflerin dışında söz konusu dönemde eseri kaleme alanın içtimaî hayattaki yerinin eserlerine yansıdığı da bir gerçektir. Devlet adamı sıfatıyla hatıratını kaleme alan Sa'id Paşa'nın hatıratına devlet adamı ciddiyetinin sirayet ettiği rahatlıkla gözlemlenmektedir. ${ }^{7}$ Osmanlı münevverlerince kaleme alınan eserlerde bulundukları mahfillerde yaşanan tartışmaların seviyesi ve çerçevesine dair bilgileri içeren hatıraların da bulunduğunu belirtmek yerinde olacaktır. ${ }^{8}$ Dolayısıyla toplum katmanları dahilinde bulunulan mevkiinin genel halinin bu eserlere yansıdığ rahatlıkla ifade edilebilir. Daha çok siyasi-politik meselelerle yoğun irtibatlar içerisinde bulunan kişilerin kaleme aldıkları hatıratlarda hadiselerden kendini azade kılmak, temize çıkarmak ya da şahsi ithamlara cevap vermek maksadı güdüldügü görülmektedir. Nitekim bu bakımdan oldukça sıkıntılı dönemlerde devlete vaziyet eden isimlerden biri olan Talât Paşa'nın hatıratının hemen giriş kısmında hatıratını kaleme almaktaki maksadına dair ifade ettikleri bu duruma iyi bir örnek olarak gösterilebilir. Talât Paşa birçok kişinin hatıratını yazması için teşvik ettiğini hatta bu hususta kendisine paralar teklif edildiğini belirttikten sonra kendisinin bir hatırat değil de tarihi bir eleştiri yazmak niyetinde olduğunu belirtmekte ve " ...yüzyıllardan beri süregelmişsinsi bir siyasetin bu gün Osmanlı Devleti’ne dilediği şekli vermek üzere ileri sürdügü̈ haksız suçlamalara cevap olarak yazmaya karar verdim " cümleleriyle hatırat yazma sebebini izah etmektedir. ${ }^{9}$ Buna ilave hatırat yazma gerekçesini ait olduğu milletin farklı milletler nezdindeki yanlış kanaatlerini tadil etme şeklinde izah eden Halil Halid gibi isimler de mevcuttur. Halil Halid "Bir Türk'ün Ruznamesi” adlı eserinde Batı Avrupa ülkeleri içerisinde Türkler hakkında en fazla yanlış kanaate sahip olanların İngilizler olduğunu beyanla; “...bazı İngiliz refiklerim tarafindan Türkiye hakkında Türklük nokta-i nazarından bir kitap yazmam istendi...” cümleleriyle bir anlamda Türkler/Türklük hakkındaki kanaatleri tadil etme gayreti içerisinde olduğunu ifade etmektedir. ${ }^{10}$

Hatırat türü eserler için şunu da belirtmek gerekir ki müstakil kitap olarak kaleme alınan eserlerin yanı sıra gazete ve mecmualarda tefrika şeklinde neşredilen, daha gündelik münasebetler ve hadiseler üzerinden kaleme alınmış hatıratlar da mevcuttur. Bu hususta İkdamcı Cevdet namıla

6 Ali Birinci, “Hatırat Türündeki Kaynakların Tarihi Araştırmalardaki Yeri ve Değeri”, Atatürk Araştırma Merkezi Dergisi, 41, 1998, s. 613-615.

$7 \quad \mathrm{Bu}$ eser genel anlamda tetkik edildiğinde gerek üslup gerekse meseleleri aktarma biçimi bakımından önemli bir eserdir. Küçük Mehmed Sa'id Paşa'nın Hatıratı-Sultan II. Abdülhamid'in Sadrazamı- 3 Cilt, Yay. Haz. Mustafa Gündüz, Ketebe Yayınevi, İstanbul 2019.

8 Hüseyin Cahit Yalçın, Edebiyat Anıları, Basıma Haz., Rauf Mutluay, Türkiye İş Bankası Kültür Yayınları, İstanbul 1975, s. 93-96.

9 Talât Paşa’nın Anıları, Yay. Haz. Alpay Kabacalı, Türkiye İş Bankası Kültür Yayınları, İstanbul 2000, s. 17.

10 Halil Halid, Bir Türkün Ruznamesi, Klasik Yayınları, İstanbul 2008, s. XVII. 
anılan Ahmet Cevdet (Oran)'ın İkdam gazetesinde yayınlanan “İsviçre Hâtırâları" başlıklı metinleri dikkat çekicidir. Nitekim bu metinlerde anlattıkları bir Osmanlı münevverinin batı tahayyülüne dair de önemli ipuçları barındırmaktadır. ${ }^{11}$ Sâmi Pâşâzâde Sezai'nin "İsviçre Hâtırâtı" başlığıyla Edebiyat-ı Umumiye Mecmuası'nda kaleme aldığı metinler ${ }^{12}$ ya da Halil Sami'nin "Rusya Hâtırâtımdan" başlığıyla Tearüf-i Müslimin mecmuasında neşrettiği hatıralar $1^{13}$ muhtevalarının önemine atfen örnek olarak gösterilebilirler. Bunlara ilave edilebilecek bir diğer hatırat ise Abdurrahman Adîl (Eren)'in Osmanlı matbuat hayatına dair hatıralarını ihtiva eden metinleridir. Yazdığı hatıratın kıymetini belirleyen önemli hususların başında Abdurrahman Adîl (Eren)'in Osmanlı matbuat hayatında önemli bir yerinin olması gelmektedir. Nitekim Abdurrahman Adîl Bey Vilayet, Tercüman-1 Hakikat, İkdâm, Cerîde, Ma‘ârif, Peyâm, Tevhid-i Efkâr, Resimli Ay, Şehbâl, Yarım Ay, Akşam, Vakit, Cumhuriyet gibi gazete ve mecmualarda yazı ve şiirleri ile yer almış bir isimdir. Bunlara ilave bizzat kendisi tarafindan yayınlanan Azim, Şu'un, İnkılâb, Şuur ve Mesai, Hadisât-1 Hukûkiye ve Tarihiye isimli mecmualar da bulunmaktadır. ${ }^{14}$ Abdurrahman Âdil (Eren) matbuat âlemindeki yeri ve hukukçu kimliği dolayısıyla Osmanlı ve Türkiye Cumhuriyeti için önemli isimlerden biri olmuştur. Gerek kaleme aldığ ş̧iir ve yazılarıyla dahil olduğu gerekse kendisi tarafından neşredilen mecmua ve gazeteler üzerinden son dönem Osmanlı matbuat hayatında hiç kuşkusuz önemli hatıraları bulunan bir isimdir. Hal böyle olunca sosyal, siyasî, kültürel hayatın ne şekilde olduğu ve hatırat kaleme alanın ve onun yaşadığı dönemin düşünce dünyasını anlamak bakımından bu tür eserlerin kıymetli olduğu gerçeğinden hareketle son dönem Osmanlı matbuat hayatının ahvalinin ne şekilde olduğuna dair önemli bilgileri ihtiva ediyor olmasından mülhem bu çalışmada Abdurrahman Adîl (Eren)'nin İkdam gazetesinin sekiz sayısında neşrettiği hatırat metinlerini transkript etme yoluna gidilmiştir. Hatıratın müstakil kitap şeklinde neşretmek için yeterince fazla sayfada olmaması bu tür bir neşri gerektirmiştir.

\section{MATBU'ÂT-I OSMÂNIYY HÂTIRALARI ${ }^{15}$}

\section{Ahmed Rasim Bey, Ahmed Cevdet Bey, Arak Saraciyan, Münîf Paşa, Takvîm-i Vekayi, Karakoc Efendi, William Curhchill, Cerîde-i Havâdis, Corchill'in Oğlu, Tahsîsat, Ruznamçe-i Cerîde-i Havâdis, Gazetecilerde Şeyhü’'l Reis, Münîf Efendi ve Şinâsi, Nâmık Kemâl Bey, Subhi Paşa, Sultan Hamîd-i Sanî, Şeyhinoğlu, zannedersem.}

Ahmed Rasim Bey bahsi açtı. Ahmed Cevdet Bey tazeledi. Matbu'ât-1 Osmâniye târîhi pek merak ettiğim bu cihettir. Maatteessüf tetebbu'ât ve ma'lûmâtı pek azdır.

Matbu'âtı Osmâniye târîhine dair üç eser manzûr olmuşdur. Bunların bir nüshası Münîf Paşa tarafından yazılmıştır. Münîf Paşa Meclis-i Ticaret Reis-i Sanîsi iken bir makale yazdı. Tasvîr-i

11 Hidayet Kara, "İkdamcı Cevdet'in İsviçre Notları Işığında Osmanlı Aydınının Batı Algısı", History Studies International Journal Of History, 10/7, 2018, s.163-184.

12 Sâmi Paşazâde Sezai, “İsviçre Hâtırâtı”, Edebiyat-1 Umumiye Mecmuası, 1/14, s. 241-244. Sâmi Paşazâde Sezai, "İsviçre Hâtırâtı", Edebiyat-1 Umumiye Mecmuası, 1/15, s. 257-258.

13 Halil Sami, "Rusya Hâtırâtımdan -I", Tearüf-i Müslimin, 1/10, s.164-166. Halil Sami, "Rusya Hâtırâtımdan -II", Tearüf-i Müslimin, 1/12, s.195-197. Halil Sami, "Rusya Hâtırâtımdan -III", Tearüf-i Müslimin, 1/14, s.229-231.

14 Ali Turan, “Abdurrahman Âdil Eren'in (1868-1942) Hayatı, Eserleri ve Mahkeme-i Temyiz Adlı Eserinin Tahlili”, Türk Hukuk Tarihi Araştırmalarl, 23, 2017, s. 57-80. 
Efkârın zuhurunu tebşir etti. Tasvîr-i Efkâr 1278 senesi zilhiccesinin son günü intişâr etmiştir. Münîf Efendi'nin makalesi de 1279 senesi muharreminde yazılmıştır. Devlet-i Osmâniye'de ilk gazete Takvîm-i Vekayi'dir. 1247 senesi Cemaziyelevvelinin yirmi beşinci günü ilk nüshası intişâr etmiştir. Binâ'enaleyh devr-i Mahmûd Hânîye musâdiftir. Mezheb olarak mücelled bir büyük cildi tamk'ul hurûfda mevcûd idi. Maatteessüf yazdı. Fakat Takvîm-i Vekayi'nin bir takvimi (Koleksiyon) Karakoc Serkiz Efendi'de mevcûdtur. Serkiz Efendi lütfederlerse Takvîm-i Vekayi münderecatı ve o zamanın vukuatı hakkında mükemmel bir menba' elde bulunmuş olur. Karakoç Serkiz Efendi Devr-i Meşrutiyet’te Müdevvenat-1 Kanuniye müdüriyeti yaptı. Tertib-i sanî düsturlarımızı ahseni takvim üzere tertib etti. Meydânda bulunan yedi cilt, himmetinin büyüklüğüne bir handır. Kendisinden daha pek çok hizmetler beklenir.

Memalik-i Osmâniye'de gayrı resmî Cerîdelerin birincisi William Curchill'in eseridir. Bu zât İngilizdir. O da devr-i Mahmûd'ide neşre başlamıştır. Gazetesinin ismi Cerîde-i Havâdistir. Bu gazete 1256 sene-i hicriyesinde intişâr eylemiştir. Takvîm-i Vekayi gibi bu gazete dahi haftada bir neşr olunur idi. Münîf Efendi kitâbında bulunmuştur. $\mathrm{O}$ zaman gazete muharriri denmez gazete kâtibi denilir idi. Mu'ahharen Tercümân-1 Ahvâl Gazetesi de neşr olunmakla Cerîde-i Havâdis rekâbete ma'rûz oldu. Cerîde-i Havâdis de yevmi intişâra başladı. Mebadide yevmi bir yaprak olarak neşr olunuyor idi. Mu'ahharen iki yaprağa iblağ olundu. İsmi (Ruznamçe-i Cerîde-i Havâdis) idi. Hafta'lik Cerîde-i Havâdis yine intişâra devâm etti. William Curchill 1262-1263 senesinde vefat etti. Oğlu yerine kaim olarak gazeteye devâm eyledi. Taraf-1 devletten mahsûs 2500 kuruş maaş ve gazetenin rusatnamesi oğluna devrolundu.

Devlet-i Osmâniye' de üçüncü gazete Tercümân-1 Ahvâldir. Tercümân-1 Ahvâl'dir. Tercümân-1 Ahvâl gayrı resmî olarak bir Türk’ün çıkardığı ilk gazetedir. Demek millî gazetelerimizin en kıdemlisi Tercümân-1 Ahvâl'dir. Bunun muharriri Şinâsi merhûmdur. Türk gazetecileri için ilk millî bir gazetenin ilk muharriri olmak üzere Şinâsi zuhur etmiştir. Eğer gazetecileri için bir şeyh'ül reis arayacak olursak bu unvânı Şinâsi merhûma vermek icap edecektir. Cerîde-i Havâdis'in ilk muharriri kim olduğu meçhûldür. Cerîde-i Havâdis muharrirlerinden, o zamanki tabir üzere Kâtiplerinden yalnız Ayıntabi Münîf Efendi ma'lûmdur. Fakat Münîf Efendi bihakkın bir gazetecidir. Kavâ'im ${ }^{16}$-i nakdiye hakkında yaptığı tedkîkât, matbu'ât-1 Osmâniye târîhini yazmak gibi İbdâ't, Münîf Efendi'ye başka bir kıymet ve ehemmiyet verir. Ne Tasvîr-i Efkâr ve ne de Tercümân-1 Ahvâl takvimlerini görmediğimden gazetecilik i’ticâriyle Şinâsi’ye ne kıymet vermek lâzım geldiğini takdîr edemem. Şinâsi merhûmun mücellid-i Lisanı Osmanî olduğu makâlatı, işarı ile anlaşılıyor. Şinâsi merhûmun lisâna hidmetinde gayrı ulûm ve funûn şitade sâhîb-i yed dolu bir zât olduğu kendisini pek yakından tanımış olan bir zattan biliyorum.

Bu zât Avukat Toros Saraciyan Efendi idi ki Nâmık Kemâl Bey merhûmu mahkeme-i cinayet huzûrunda müdâfa'a etmişti. Mahkeme-i Cinayet o zaman Suphi Paşa merhûmun taht-1 riyâsetinde in'ikâd eder idi. Nâmık Kemâl Bey merhûmun (şihan oğlu) Abdulhamîd-i Sanî’ye jurnal etmiş idi. $\mathrm{Bu}$ (şihan oğlu) kimdir? Fakat jurnale sebeb ve mevzu:

Bade, arak tükendi saki getir müselles

Eşşey-ü lâyüsenna illâ vekad yüselles

Beyti olduğunu bilirim. Vâkı'anın tafsilatı Kemâlzâde Ekrem Bey Efendi hazretlerince 
ma'lûm olmak lâzım geldiğinden latf/lutf tahrîrleri muntazırdır.

Toros Saraciyan Efendi derdi ki: Şinâsi merhûm ansiklopedinin (Encyelopédique) bir adam idi. Zamanın ulûm ve funûnunda behra-i kâmile sahibi idi.

Münîf Paşa'yı pek yakından tanıyorum. Dersinde bulundum ve meclis-i irfânına pek çok mülâzemet etdim. Münîf Paşa da ansiklopedik bir adam idi. Zamanında ulûm ve funûnu pek iyi biliyor idi. Münîf Paşa'da bir haslet daha var idi ki o da pek çok lisân-1 ecnebiyeye vukûfiyyettir. Fransızcadan ve Arabi'ye ve Farsiyeden gayrı olarak, Almanca, İngilizce biliyor ve konuşuyor idi. Hatta Sanskrit lisânına dahi merak etmiş idi. İbranice dahi okur idi. Meclis irfânında Araplar, İngilizler, Hindular hatta bazen Çinliler bulunur idi. Mübâhase ${ }^{17}$ ekseriyen lisân üzerine cereyân ederdi. Keşfiyat-1 cedîde de mevzubahis teşkîl ederdi. Hele zafvet lisâna pek çok merak ve itina ederdi. Herhangi bir galat sözü derhâl tashîh ederdi. (Zannedersem) galat-1 şayi’i sinirine dokunur, derhâl târîhtâr edip sahihini tekrâr ettirirdi. İmdir gazetecilerin şeyhü'l re'îsi Osmanlılarda kim tanınmak lâzımdır meselesini hal ederken bu iki namzet yek diğerine rekâbet edecektir zannederim. Ta'yîn rüchan veya bir şahıs-1 salise tevciye unvân netice-i tetebbuata mahuldür.

$\mathrm{Bu}$ satırları min ğayri ta'ammüd yazdım. Kalemi elime aldığım zaman maksadım bunları yazmak değildi. Maksadım Ahmed Cevdet Bey'in bu sabahki makalesini girizgâh ittihaz ederekyine Ahmed Cevdet Bey'in geçen sene Ahmed Rasim Bey'e hitâben yazdığım bir fikra üzerine karaladığım bir hâtırât-1 zatiye müsveddesini nakl ve tebyîz etti. İnşallah anı da yakında arz ederim.

\section{MATBU'ÂT-I OSMÂNIYE HÂTIRALARI ${ }^{18}$}

\section{Şinâsi’nin Fikri, Ebuzziyâ Tevfik Bey, Hâce Tâhir Efendi, Taksim Mezarlı̆̆ı, Çingane Karakolu, Tophaneli Vefik Bey, Binbaşı Muhiddin Bey, Binbaşı Halil Bey, Şinâsi'nin Hanesi, Kamusü'l Ulum, Operatör, Fikri Paşa, Turus Efendi, Ahmed Rasim Bey, Ahmed Cevdet Bey, Matbu'ât-ı Osmanîye Cemiyeti.}

Şinâsi merhûma mu'âsır ve müsâdif olmuş zevâtın üç şahıs ile tanışdım. Bunlardan birincisi Ebuzziya Tevfîk Bey, İkincisi Abdurrahman Şeref Efendi, üçüncüsü Avukat Serracoğlu Toros Efendi'dir. Abdurrahman Şeref Efendi Şinâsi'yi Eyyub Semti'nde gördüğünü ve fakat o zaman dimâğ 1 tel'in edildiğinden bir şey konuşamadığını söylemiş idi. Ebuzziyâ Tevfík Bey'in ma'lûm ve mahfûzu olan husûsâttan mühim bir şey bit-tesâdüf vâsıl sem' ttlâm olmuşdur. Ona da sebeb borsa mu'âvini Hâce Tâhir Efendi hazretleridir. Şöyle ki: 1910 senesi sonbaharında bir perşembe günü akşama yakın Ebuzziyâ merhûmu ziyâret etdim. O zaman Ebuzziyâ Tevfík Bey Tasvîr-i Efkâr neşr ile meşgûldü. Matba'a divân yolunda Senedât Müdürü Salih Efendi hânesinin alt katını teşkîl ederdi. Medhâlinden girilince solda câmekân ile ayrılmış bir oda vardı. Ebuzziyâ merhum bu odada büyük bir yeşil masanın vasatında oturur, çalışır idi. Ziyârete vardığım zaman masanın diğer başında gözlüklü, siyâh sakallı, beyaz çehreli bir zât oturuyor idi. Ebuzziyya Tevfîk Bey hem yazı yazıyor hem de konuşuyor idi. Bir müddet söz kesildiğinden sonra bu zât sordular ki:

\section{Şinâsi'nin kabri nerededir?}

Pek teyakkuz ve intibâhımı mûcib olan bu sual hiçbirimizin hatırlamadığı fakat cümlemizin irâd etmesi lâzım gelen bir sual idi. Evet, muhibbi ve müceddi lisân olan Şinâsi nerede yatıyor?

17 Bir harf eksik..

18 İkdâm, 18 Rebiülevvel 1340, Nu: 8864, s. 4. 
Medfen neresidir? Sâyesinde bu günkü yazıyı yazmakta olduğun zât nerededir? Başımı kaldırdım; Ebuzziyâ Tevfîk Bey’in vereceği cevâbı dört göz ve dört kulakla duymak istiyordum.

Şinâsi'yi taksîm kabristânına defnettik. Taksim'den Almanya Sefarethanesine giderken sol kolda bir karakol vardır. Bu karakol Abdulhamîd yapdırmışdır. Bu karakola Çingâne Karakolu diyorlar. Karakoldan aşağıya doğru gidilince yine solda ufak bir kapu tesâdüf ider. İște bu kapudan Şinâsi'nin tabutunu geçirdik. Sola mâ'ilen giderek kırk adım ileride Şinâsi’yi defnettik. O zaman kabrini yaptırmadık. Ve bir taş da dikemedik.

Kabrin mevkii meçhûl kalmak içün sûret-i mahsûsa da adımladım. Kapudan kabre tam kırk adım idi. Geçen bana bunu Muhyiddin'de (o zaman Beyoğlu Mutasarrıfı Binbaşı Muhyiddin Bey’e mu'ahharan yine gitmişdir. Fi'l-hal Anadolu'ya ifâyı vazîfe etmekte bulunmuş olan Muhyiddin Paşa bu zât olsa gerek) sordu. Belki kabri arayub bulmuş hatta üzerine bir şey’de yabdırmışdır. Bir kere Muhyiddin'i görüb sorunuz.

Ebuzziyâ Tevfik Bey’in bu cevâbı üzerine muhatab olan zât Muhyiddin Bey’i görmeyi ve icabına bakmağı va'ad eyledi. Meğer muhatab o zaman Borsa Mu'âvini Hâce Tâhir Efendi Hazretleri imiş. Pederimin Manastır'da pek aziz ahbabından olduğunu işittiğimden kalkub elini öpdüm.

Bir müddet sonra Paris'e gitmiş ve avdetinde mebu'sanın ma'hûd harb mese'lesi zuhur iderek dünya altüst olmuş olduğundan ne kabri taharri ve ne de bir hizmet ifâsına kadir oldum.

Muharebenin üçüncü senesinde ben oğlu jandarma kumandanı Binbaşı Halil Bey’in -İkdâm Gazetesi'nde- bir tezkeresi neşr olundu. Bu zât Şinâsi'nin mezarını soruyor ve bilerek neşr-i ma'lûmat etmesini rica ediyor idi. Mesmûat-1 sâlife-yi derhâl İkdâm'a yazdım ve birkaç gün sonra gidüb Taksim Kabristanını ziyâret etdim. Ne göre...(Yim) (harf silinmiş gibi) gördüğümü yazamam. Sıkılır ve utanırım. Benim ne kadar sıkılıb utandığımı takdîr etmek isteyen matbu'ât arkadaşlarım isterlerse bir kere ta'rîf ettiğim kabristânı ziyâret etsünler.

Şinâsi'nin pederi Boluludur. Tophaneye mensub İbrahim Efendi'dir. $\mathrm{Bu}$ münasebetle olmalıdır ki Cihangir semtinde ikâmet eder idi. Şinâsi'nin hânesi Sormagir ile Taksim arasındadır. Sıra Servi Caddesi geçildikten sonra solda bir cami-i şerif tesâdüf eder. Yine sola sapılınca Sormagir yolu tutulur ve Alman Hastahanesi'nin kabl-el-harb ilâve ettiği devâire tesâdüf olunur.

Yine sola sapınca dar bir sokak gelir. Bu sokağın solunda Alman Hastahanesi’nin etfal kısmı gelir. İşte bu etfal da'iresi Şinâsi'nin hânesi üzerine inşâ edilmiştir. Bu ma'lûmâtın istihsaline de İkdâm'ın neşriyat-1 sâlifesi bâdî oldu. Binbaşı Halil Bey’in tezkeresini ve fakirin cevâbnâmesin Cihangirli Refik Bey okumuşlar. Tophane halifeliğinden mütekâ'id olan Refik Bey Efendi Ebuzziyâ Tevfik Bey'in verdiği ma'lûmâtı tasdîk ittiler filhakika mahalle ihtiyarları Şinâsi merhûmu Taksim Kabristanı'na defnettiklerini söylerlermiş. Şinâsi'nin hemşiresi yakın vakte kadar memur olmuş, Cihangir'de ikâmet eylemiş, bahriye-yi etıbba' operatör Fikri Paşa Şinâsi’nin hemşirezâdesi imiş. Bu zât esnâyı harbde irtihâlı dar-1 bekâ eylemişdir.

Refik Beyefendi Şinâsi’nin Avrupa'ya firar ettiğini ve Fransız Konsoloshanesi'nin kendisine himâye ve müzâherât eylediğini, yani Avrupa sefer ve seyahatini teshîl eylediğini de hikâye ederler.

F S Sinâsi ile görüşenlerden Turus Efendi gayet mühim bir ma'lûmât daha veriyor idi. Diyor idi ki Şinâsi çok çalışır idi. Hiç boş durmaz idi. Dâ'imâ yazar idi. En büyük merakı ve meşgûlesi bir kamus-1 ulûm cem' ve telfiki idi. Eserinin bir büyük kısmını yazmış idi. Bakalım günün birinde bu 
Kamus-1 Ulumdan bir işar ve haber zuhur eder mi?

Bugün bütün Osmanlıların ukde-i derun edecekleri nice nice husûsât vardır. Fakat matbu'ât-1 Osmâniye müntesibleri için Şinâsi'nin kabri o ukdelerin en mühimlerindendir. Allah, Ahmed Rasim Bey'den razı olsun ki matbu'ât-1 Osmâniye târîhi bahsini açdı ve Ahmed Cevâd Bey'den hoşnud olsun ki bahsi tazeledi. Matbu'âtı Osmâniye Cemiyeti bugün Şinâsi'nin ne kabrini ve ne de abidesini yaptıramaz; fakat yaptırabileceği bir şey vardır ki o da Şinâsi'nin makamı etrâfına bir tel örgü çevirmek, bir levha ta' lik etmek ve tesbît ve muhafaza eylemekdir. Şurasını da târîhtâr-1 vacib görürüm ki tesbît-i makam husûsunda ihtiyatlı davranılsın. Sağdan kırk adım ve soldan kırk adım yer tefrik ve tahdîd kılınsın. Tahkikâtın ta'mikine imkân bulunursa sonra kabrin makamı tahsîs olunur. İmkân bulunmazsa da'iren madar o makam muhafaza kılınur.

\section{MATBU'ÂT-I OSMÂNIYE HÂTIRALARI ${ }^{19}$}

\section{Beyoğlu'nda Hacopulo Çarşısı, Hacopulo'nun Terası, İbret Gazetesi, Devir} Gazetesi, Ahmed Midhat Efendi, Nâmık Kemâl Bey, Reşâd Paşa, Reji Komisyonu, Nuri Bey, Ebuzziyâ Tevfrik Bey, Üç Makale Birden, Midhat Paşa, Mu'allim Naci, Para İster Muharririn Kirâm, Kiseli Rıfat Bey, Evliya Çelebi Seyâhatnâmesi, İbret Günde İki Bin

\section{Nüsha}

Seracoğlu Turus Efendi naklettiği hâtırât meyanında nazarı dikkatimi celb iden husûsâtdan biri de Beyoğlu'ndaki Hacopulo Çarşısıdır. Beyoğlu'ndaki Hacopulo Çarşısı matbu'ât-ı Osmanîye için bir zamanlar parlak bir merkez olmuş idi. Nâmık Kemâl Bey İbret'i, Ahmed Mithat Efendi Devir Gazetesini Hacopulo Çarşısı'nda neşretmişlerdir.

Turus Efendi der idi ki: Nâmık Kemâl Bey İbret Gazetesini Hacopulo Çarşısı'nda çıkarır idi; Reşat, Nuri, Tevfík (Ebuzziyâ) Beyler, Hacopulo Çarşısı'nda (teras)da karşısına alır, ara sıra bir konyak içer, ayakta gezinir, her üç muharrirde ayrı ayrı mevzularda, ayrı ayrı üç makale söyler, yazdırır idi. Evvelen Reşâd, sonra Nuri, sonra Tevfîk Beylere hitâben istiktâba başlar, birinciye uzun bir fikra söyleyib andan Nuri Bey'e döner, andan sonra üçüncü makalenin birinci fikrasını Tevfîk Bey’e hitâb eder idi. Üç makalenin birinci fikralarını böylece takrir ettikten sonra katiyen silsile-i kelamı unutmaksızın yine Reşâd Bey'e okuna gelir birinci makalenin ikinci fikrasını ana ve sırasıyla Nuri ve Ziyâ Beylerin önlerine gelerek makalelerinin ikinci fikralarını takrîr eyler idi. Böylece her üç makale birden istiktâb olunur, cümlesi yazıldıktan sonra Kâtipleri makaleleri savt-1 cehîr ile okurlar, Kemâl Bey de dinlerdi.

Ekseriyetle hiçbir tadil ve tashîhe lüzûm görülmez, makâlat tesvid olunduğu gibi tertib ve taba' verilir idi.

Küçük çocuk iken, Midhat Paşa için böyle bir menkıbe işitir idim. Filhakika Midhat Paşa dahi önüne iki üç kâtip oturtup her birine ayrı ayrı birer mevzu' üzerine takrir ve istiktâb eder bir sâhib efendi imiş. Fakat Nâmık Kemâl Bey için böyle bir şey çocukluğumda işitmemiş idim. Turus Efendi ciddi ve doğru bir adap olub hiçbir vakitte mübalağa veya riya yapmadığı yakinen meczûmum olduğu gibi Ebuzziyâ Tevfîk Bey dahi Turus Efendi'yi pek eskiden tanıdığı ceryan-1 ahvâlden anlaş1lıyor ve Turus Efendi'ye karşı büyük hürmet ve samimiyet gösterir idi. binâ'enaley fikra-i menkulenin mükarin-i hakîkat olduğunu kabul ve tasdîk de zerre kadar tereddüd itmem. 
Turus Efendi'nin ifâdesinde sabk eden (terasa) sözü birçok zamanlar zihnimi yordu. Ve beni pek çok düşündürdü. Nâmık Kemâl Bey ve rüfekâsının Hacopulo Çarşısında nerede çalıştıklarını tespit etmek isterdim. Turus Efendi rahatsızlanmış idi. Kendisini gidip bulmaya vaktim müsa'ade olmuyor idi. Beyoğlu'ndan girip çıkmasını hala bilmediğim sokakların birinde ikâmet ediyor idi. Adresi dâ'imen ma'lûm idi. Bir iki def'a Ekrem ve Cezmi Beylere, Löbon da tesâdüf ettikçe, peder ve cedlerinin çalıştığı mevki bir mahal târîhi dimek olduğundan tespiti pek muktefi olduğu târîhtâr ve Turus Efendi'yi görmelerini istirham etmiş idim, bilmem ki muvaffak oldular mı?

(Teras) denilince kârgîr olarak üst katı hâtıra gelir. Hacopulo Çarşısı'nın sakf kısmında düz, müstevi bir yer var mı diye araştırır idim. Şayet bulunursa Kemâl, Reşâd, Nuri, Tevfîk beylerin orada çalışdıklarına hükmetmek isterdim. Fakat Tahkikâtimde böyle bir şeye müsâdif olmadım. Geçen gün yolum düştü de Hacopulo Çarşısı'na girdim.

Vasata doğru ilerleyince çarşının sağ tarafı nazarımda başka türlü tecelli etti. 1884 senesi şubatında ikinci def'a olarak İstanbul'a gelmiş, Beyoğlu'nda bir hafta ikâmet etmiş ve Hacopulo lokantasında taam eylemiş idim. Hukûk tahsîl ederken de 1304-1305 senelerin kısmen Beyoğlu'nda geçirmiş idim. Gördüğüm manzara şimdiki manzara değildi. Cümle kapısından girilince sağ tarafdaki postacı dükkânı meşhûr bir lokanta idi. Bu lokantanın bir de yazlık yemek verdiği terası var idi. Çarşının holü cihetinde desâdüf eden kısmı yerden bir, bir buçuk metreye kadar irtifa' peyda eder idi. Zemîni çakıl taşı döşenmiş etrâfına latif bir demir parmaklık çekilmiş idi. Burada yaz günleri biraz hava alarak taam ederdik. İște Turus Efendi'nin (teras) tabir ittiği, Nâmık Kemâl Bey'le avanına mahal-i içtima ve tahrîr gösterdiği yer bu yer olmak lâzım gelir. Şimdi Hacopulo Çarşısı'nın eskimiş müdüriyetini bulmalı. Hakîkaten bu teras hakkında ma'lûmât almalı. Hâlihazırda teras meşhud değildir.

Balada ismi sabk eden Reşâd Bey, Ali Ferruh merhûmun pederi Reşâd Paşa'dır. Nuri Bey de Yusûf Menapor'un babası Nuri Bey’dir. Mabeyn Kâtipliği ve reji komiserliği ile ma’rûftur.

Ma'lûmdur ki biz de matbu'ât-1 ali pek fakirdir. Müntesbin-i matbu'ât- ekseriyet üzere- bir aşk ile dergâha intisâb etmiş dervişlerdir. Bir de matbu'ât aleminde muharrir olarak geçinmek pek güç bir iştir.

Naci merhûm Tercümân-1 Hakîkat'a intisâb etmiş, haftanın birinde idare memuru haftalığını veremeyince:

Para ister muharririn-i kirâm

Sahib-i imtiyaz hayrette

Kıtasını söylemiş idi. Filhakika Tercümân-ı Hakîkat çömezliğimde idare memuru Ahmed Cevâd Efendi'nin bazı muharririn-i kirâma haftada ikişer mecidiye verdiğini pek iyi hatırlarım (1301-1302) ne hacet! Koca Evliya Çelebi Seyâhatnâmesi’ni Pertev Paşa Kütüphânesi'nde istinsah ile esnâyı tahsîlinde temin-i maişet etmiş olan küliyesi Doktor Rıfat Bey de -her hafta iki furmalık yazı istinsah etmek şartıyla- iki Mecîdiye alır, anla hem kendi hem de nafakası üzerine vacib olanlar infak olunur idi. Fakat Turus Efendi'nin verdiği ma'lûmâta göre İbret Gazetesi muharrirleri böyle değildi. Nâmık Kemâl'in kalemi fevkalade bir kuvve-i teshiriyeye malik olduğundan İbret Kemâli revacda idi. (İbret)İn yevmiye iki bin nüshası tab' olunur, birer kuruşa satılır, bir tek danesi kalmayarak halk beyninde kapışılır idi; her bir refik günde dört- beş lira altun akçe hisse-i temettü alur idi. Nâmık Kemâl ve a'vânı İbret'i çıkardıkça pek merak başlar idi. 


\section{MATBU'ÂT-I OSMÂNIYY HÂTIRALARI ${ }^{20}$}

Ahmed Midhat Efendi- Tercümân-1 Hakîkat- Ebu Su'ud Caddesi- Fransızca Türkçe Osmanl1Selanikli Tevfîk Efendi- Karşı Gazeteleri- Muhbir Yok - Selanik de Mekteb-i Terâkkî ve Edebiyat Dersi-Seyr Eyleyin Gümbürtüyü- Selanik'de Vilayet Gazetesi- Marsilyatın Semaforu- Aynaroz'da Rus Müessesat1- Matbu'ât-1 Osmâniyede Fikdan-1 Rüşt

Ahmed Midhat Efendi Tercümân-1 Hakîkat ile bu milletin irfânına büyük hizmetler etmiştir. Tercümân-1 Hakîkat şimdi olduğu gibi Ebu Su'ud Caddesi'nde neşr olunur idi. Fakat matba'a binâsı şimdiki binâ değildi. Şimdiki binâdan az sonra gelen çifte hâneler idi. Birincisinin üst katında Fransızca-Türkçe olarak neşr olunan (Osmanlı) gazetesi heyet-i tahrîriyesi bulunur idi. İkinci binânın orta katında da Ahmed Midhat Efendi çalışıyordu. Midhat Efendi istisna edilince, Tercümân-1 Hakîkat heyet-i tahrîriyesinde en çok hizmet ifâ eden Selanikli Tevfîk Efendi idi. Tevfîk Efendi mahreç-i aklâm me’zûnudur. Mahreç-i aklâm ser 'asker 'Askeriye vukûflu Kâtip yetiştirmek üzere Harbiye Nezâreti tarafından te'sis edilmiştir. Beyazıt Meydânı'nda misafirhane namıyla yad olunan ve Bakırcılarda köşe başını teşkîl eden binâ dâhilinde bu mekteb te'sis olunmuş idi. Tevfîk Efendi mahreç-i aklâmı ikmâl ettikten sonra Tercümân-1 Hakîkate intisâb etmiş, Ahmed Midhat Efendi'nin irşâdâtıyla Pek çok tevsi'-i ma'lûmât eylemiş bir sahib-i kalem idi. Sade ve selis ve pek çabuk yazar idi. Fransızca tercümede büyük birer suh ve melekesi var idi. Levant Herald veya Monitör Oryantal'i eline alır, bir taraftan göz gezdirir, diğer taraftan bila-tereddüt ve tevkîf tercümesini yazar veya istikbâh eder idi. O zaman Tercümân-1 Hakîkat veya Osmanlı'da muhbir kullandığını ve hatta telgraf abonmanı yapıldığını hatırlamıyorum. Akşamüzeri çıkan İstanbul, Levand Herald, Monitör Oryantal matba'aya gelir ve Havâdisleri- dâhilî, haricî- tercüme olunarak Tercümân-1 Hakîkate geçirilir ve Avrupa telgrafnameleri de bu gazetelerden iktibâs olunur idi. Devâir-i devlete dair olan Havâdisleri bazı aklâm efendileri- mahiyeten- bir matba'aya getirirler idi. Geçenlerde irtihâl eden meşihu'l muhbirin Ahmed Efendi sonradan Tercümân-1 Hakîkate intisâb etmiştir. 1301 de Ahmed Efendi Tercüman-1 Hakîkat de değil idi. Karşı Fransızca gazetelerinin havadisleri kâfi görülür, Rumca ve Ermenice için de mütercim bulundurulmaz idi. Selanikli Tevfîk Efendi'nin başlı başına gazete umur-u tahrîriyesini tedvir ettiği günler eksik değil idi. Bununla beraber Tevfîk Efendi kendi nam ve hesabına romanlar tercüme etmeye yine vakit buluyor idi. Tevfîk Efendi göl altında örtülmüş kora benzer idi. Zâhiren hiçbir şeyi görünmez, güler yüzlü, mahviyetli, üstü başı ihmâl edilmiş derviş nihad bir kimse idi. Bir kere olsun hiddet ettiği, kimsenin kalbini incittiği görülmemiştir. Zaten devr-i Aziz mirâsı olan terbiye-i Osmâniyenin muktezası bu idi. O zaman matba'ada Midhat Efendi istisna edilirse hiddet eder, şiddet eder, hiddetle şiddetle lakırdı söyler kimseye tesâdüf ettik mi hatırlamıyorum, o başka bir alem, başka bir hayat, başka bir müvaneset idi. O terbiye-i hakikiye-i İslâmiyenin ashabı ve âsârına fi zamanına pek nadir tesâdüf ederiz.

Selanikli Tevfîk Efendi Cerîde-i ‘Askeriye’de de pek çok seneler hizmet etmiştir. Birçok mekteplerde Fransızca dahi göstermiştir. Sessiz, sedasız, davasız, dağdağasız çalışmıştır.

Tevfîk Efendi merhûm 1297 veya 1298 senelerinden birini Selanik'de geçirmiştir; Mekteb-i Terakki'de kinâyet ve edebiyat dersi vermiştir.

Merra binâ Mukartakun ve vechuhu yahkî el qamer. 
Qultuebû Lu'luu, minhu huzû se'ra Umar. ${ }^{21}$

Yerden göğe küp dizseler,

Birbirine perk etseler,

Altındakini çekseler, seyreyleyin gümbürtüyü

Beyitler ders esnâsında irâd ettiği misâllerden olmağla talebenin hoşuna gitmiş ve münasebetli, münasebetsiz irâd ve tekrâr edilen adat edilmiş idi.

Tevfîk Efendi Selanik'de bir seneden ziyâde duramadı. İstanbul'a avdet edip matbu'âtta ve ale'l-husûs Cerîde-i ‘Askeriye ve Tercümân-1 Hakîkat'te çalıştı. Yaz ta'tîllerinde Selanik'e gelmek mutadı idi. Fakat yine boş durmaz, Selanik’e gelince vilayetin resmi gazetesini neşr ile iştigâl eder idi. Vilayetin resmi gazetesi vilayetin mektûbçusu veya mektûbî kalemi mümeyyizi tarafından neşr edilmek mutad idi. Selanik mektûbî kalemi mümeyyiz Tevfîk Efendi, Vasıf Efendi bu vazîfeyi görürlerdi. Fakat Tevfîk Efendi Selanik'e gelince onlara iş bırakmaz, bütün vazîfeyi deruhte eyler idi. Selanik'in o müthiş sıcağında bütün gün, bütün gece çalışır, seve seve, güle güle yazılarını yazar idi. Matbu'ât aleminde ilk yazılarım Tevfîk Efendi'nin ta'tîl ziyâretlerinde başlamıştır. Elime Larusun (izhar-1 târîhiye)sini sıkıştırmış, bazı parçalarını tercüme ettirerek imzam tahtında Selanik resmi gazetesine derç etmiş idi. Aynaroz Manastırları hakkında Marsilya’nın Semafor gazetesinden mühim ve büyük bir bendi dahi kendi reyimle tercüme etmiş idiysem de zülfü yâre dokunduğundan resmi gazeteye konulamamış idi. (Semafor)un Selanik muhabiri Aynaroz manastırlarını gezmiş, Rusya'nın bu manastırları birer istinâdgâh-ı harb ve fesâd olmak üzere hazırladığını uzun uzadıya ta'rîf ve 'izâh eylemiş idi. Matbu'ât-1 Osmâniyenin hiçbir hakîkati gereği gibi ifâdeye me'zûn ve ehil olmadığına ilk hasıl ettiğim kanaat o zamandandır. Rusya bahr-1 sefidin müstahkem bit'tab' bulunan bir noktasını deyniyat maskesi altında makasıd-ı siyâsiiyesine istinatgâh olmak üzere ihzar etsin, bir Fransız gazetesi bunu bütün ve vuzuh ve teferruatıyla yazısında Osmanlı matbu'âtı bundan bahs edemesin; bu benim için havsalaya sığmaz bir hal idi. Aradan kırk sene geçtiği halde matbu'ât-1 Osmâniyenin rüşd-ü siyâsiiyesini isbât ve istihsal edemediğine şimdi o günkü kadar müteaccib ve mugayyir olmuyorum. Ve misâlen matbu'ât-1 Osmâniye menâkıbı veya târîhi yazılıyorken elli iki sene evvel neşr edilmiş olan (Devir) gazetesinin ilk ve son nüshasında derç ettiği bendi bu gün dahi matbu'ât-1 Osmâniye sütûnlarında nakl ve tekrâr ehl ve kader olamaz ise Ahmed Midhat Efendi’nin kızdığı ve Ebuzziy Tevfîk Bey’in sıkıldığı kadar kızıp sıkılmıyorum. Ve bunlar netâyici târîhiyedir diyorum.

\section{MATBU'ÂT-I OSMÂNIYYE HÂTIRALARI ${ }^{22}$}

Ahmed Râsim Bey matbu'ât-1 Osmâniye târîhini zabt ve kayda çok hizmet etmiş bir muharririmizdir. Bundan iki sene evvel Lehli muhtedî (Hayreddin) için yazdıklarını okumuş ve Hayreddin'i pek yakından görmüş, tanımış olduğuna kanâat etmiş idim. Hayreddin'in asıl ism-i asliyesi (Karskî) olduğunu Ebuzziyâ Tevfîk Bey yazmışdır. Ahmed Cevdet Bey de bunu te'yid ediyor. Osmanlı Gazetesinde Hayreddin'in yazıları baş makaleye geçtiği vakidir. Bizzat Fransızca provalarını tashîh ettiğimi pek iyi hatırlarım (1351). Fakat resmen baş muharrir unvânını hâ'iz olup

\footnotetext{
21 Türkçeye tercüme edilmiş hali: "Mukartak bize uğradı. Yüzü ayı andirlyor (anlatiyor)du. Dedim ki Ebu Lu'lu; ondan alın Ömer'in öcünü.” Arapçadan latin harflerine dönüştüren ve tercümesini yapan Necdet Balkı'ya çok teşekkür ederiz. 
olmadığı meselesinde sûret-i kat'iyyede bir ma'lûmât dermeyan edemem.

Hayreddin yazdıklarını ekseriyetle hariçde ve ihtimal ki Balık Pazarı meyhânelerinde yazar, paltosunun cebine yerleştirir, matba'aya mest la-ya'kıl bir halde gelüb verirdi.

Osmanlı Gazetesi idârehânesinin merdibanlarını- iki taraftan tutuna tutuna çıkar, ağzındaki piposu tütmekte olduğu halde, çamur lekeleriyle malı koyu kahverengi paltosunun cebinden çıkarır, Tevfîk Efendi'ye (Selânikli) uzatır, doğruca yüne girer, kirli matba'a kâğıdı parçaları üzerine uzanır, homurdana homurdana uyku çekmeye başlar idi. Lehli Hayreddin Bâsiret gazetesinin te'sisinde dahi bulunmuş, ilk muharrirler arasına girmiş olduğunu Bâsiretçi Ali Efendi kaydeder. Lehli Hayreddin gayret-i milliye sahibi bir vatanperver imiş, Lehistan'ın taksîmine dayanamamış, terk-i dar ve diyar ederek İstanbul'a gelmiş o zaman işittiğim rivâyet böyle idi.

Lehli Hayreddin'in Fransızcaya olan vukûfu harikulade idi. Getirdiği müsveddelerde ne bir düşük ibare ve ne de çizilmiş bir fikra veya kelime gözüme ilişmemiştir.

Mösyö Astiye Astier namında bir Fransız da Osmanlının ser muharrirlik vazîfesini senelerce ifâ etti. Mösyö Astiye otuz, otuz beş yaşlarında incerek, sarı ve kırpık bıyıklı bir zât idi. Osmanlı idârehânesinde müsâdif olduğum devâmlı muharrirlerden biri de Nikolaki Solidi Efendi idi.

Tercümân-1 Hakîkat'e yazı yazanlardan biri de Tıbbiye-i ‘Askeriye mu'allimlerinden Miralay Doktor Şevki Bey idi. Bu zât hükümet tarafından Yemen'e gönderilmiş Arapların kendilerine mahsûs olan usul-1 tedavilerini tedkîk etmiş idi. Bunlar meyanında (ki) tabir olunan dağlama usulünü dahi ta'mîk eylemiş idi.

Türk mesâi'si, Osmanlıların medeniyet-i İslâmiyeye olan büyük hizmetlerini ilk zihnime koyan Midhat Efendi oldu. Bana sorarlarsa ilk Türkçü kimdir?

-Ahmed Midhat Efendi'dir. Cevâbını veririm. Midhat Efendi Türkçülük bahsinde zemaneden korkardı. Medeniyet-i İslâmiyede Türklerin büyük hizmetini ağza almaktan ictinab eder idi. O zamanın zihniyetini, muhîtini, muhîtinin cehl-i taasubkârâne ve taasub-u câhilânesini idrak için bu fikre güzel bir şâhiddir. Türkçülük davasına kıyam etmek Türkün Araba fazl ve takdimini iddia etmek demek idi. $\mathrm{Bu}$ ise istihfâf-1 din manasına haml olunurdu. $\mathrm{O}$ zaman bu mananın tevsi'ine mütehammil değil idi. Midhat Efendi'nin sözü Fransızcaya çevirmesindeki illet bu idi. Bu güzel sohbeti Tercümân-1 Hakîkatin en üst kat perde-bânından bir iki basamak inerek dinledimdi. O lezzet, o intâ'ât-ı latife hatır nişanımdır.

Geçmiş zaman olur ki hayali cihân değer

Midhat Efendi çok ve mütenevvi yazı yazmakda harika sahibi idi. Bir gün matba'ada eskiler hikâye edilir ki:

“... Efendi hazretleri kızdı: Mu’allim Naci’yi, Şeyh Vasfi'yi ve bütün muharrirleri ve hatta musahhihleri matba'adan çıkardı. Tercümân- Hakîkati yalnız başına yazmaya başladı. Baş makaleyi kendi yazdı. Telgrafları, havâdisleri kendi tercüme etti. Romanın tefrikasını da kendi yazdı. Provaları da kendi tashîh etti. Bu hal böylece dokuz gün sürdü. (Efendi Hazretleri) boza destisini önüne kor, bir taraftan boza içer ve bir taraftan yazı yazar. (Efendi Hazretleri) ne tütün içer, ne de kahve..."

$\mathrm{Bu}$ rivâyetleri kemâl-i safvetle dinlerdim. Efendi Hazretlerinin sigara içtiğini 1304 ziyâretimde dahi hatırlamıyorum. Fakat 1304 meclis-i sıhhiyede ziyâretimde ikilik paketi önüne 
koymuş, mütemadiyen sigaranın birini sarar, yakar bir taraftan da yenisinin hazırlar görürdüm: Bozaya da ibtilâsı da şayan-1 istibad değildir. Çünkü Rumeli'nden, Bulgaristan'dan idi. İri boylu, kalın kemikli, çenber siyâh sakallı idi. Sevilişi pek tatlı değildi. Fakat çok behhas idi. Asla şemsiye taşımaz, arabaya binmez, her yere yayan gider gelirdi. Hatta yazları- Beykoz'daki çiftliğinde otururdu. Bu çiftliğe dahi yayan gidip geldiğini Yani Adamandyadis Efendi nakl ederdi. Yani Adamandyadis Efendi Midhat Efendi ile karabet-i sahraya peyda etmiş Boyacı Köy Rum Mektebi Mu'allimi, fazılâdan ve ashâb-1 kemâl-i arifândan bir zât idi. Bu zât Atina darülfünunun ileri gelen me'zunlarından bulunduğu ve yirmi beş senede talim ve tedris ile meşgûl olduğu halde Midhat Efendi'nin sa'yine, irfânına, velud kalemine hayretler eder ve Midhat Efendi için Halkedros (Halkenderos) unvânını izal eder idi. Halkenderos lisân-1 Yunanî’de bakır yürekli demektir. Yunanlıların büyük bir müellifi var imiş; iki bin cild eser vücuda getirmiş; bu kadar büyük bir sa'yi izâale edipte yorulmayan bu müellife Yunanlılar bakır yürekli demişler.

Yani Adamandyadis Boyacı Köyü'nden, Karakaş ailesinden kız almış idi. Midhat Efendi'nin ikinci zevcesi Vasiliki Hatunda bu ailedendir. Led-i lahitte namı Melek Hanım tesmiye kılınmıştır.

Bir gün Yani Adamandyadis Midhat Efendi'ye sorar ki; Bu kadar çok yazı nasıl yazarsını?? Nasıl yorulmazsınız? Efendi hazretleri derler ki: “Çok yazı yazmaklığımda Vasiliki'nin çok hizmeti vardır. Ne zaman yorulup da elimden kalemi bırakacak olursam kapının yavaşçacık açıldığını ve elinde cezvesi ve fincanı olduğu halde Vasiliki'nin girmekte olduğunu görürüm. Vasiliki'nin getirdiği kahve beni dinlendirir. Tekrâr yazı yazmaya devem ederim."

Yani Adamandyadis Efendi’nin Filolog diploması aldığının yirmi beşinci sene-i devriyesini Boyacı Köyü Rum Mektebi’nde tes'îd etmişler. Midhat Efendi o gece mektebe gelip ta-be-sabah dans etmiş...

\section{MATBU'ÂT-I OSMÂNIYY HÂTIRALARI ${ }^{23}$}

Mu'allim Nâci-Şeyh Vasfi- Ahmed Midhat Efendi- Saadet Gazetesi- Mustafa Reşî̀d BeyŞark ve envar-ı Zekâ- Nigâr Hânım- Nâci'nin bir tehdidi-Sırrı Paşa-Mu'allim Cevdî EfendiAhmed Midhat Efendi ve Devr Gazetesi-Ebu'z Ziyâ Tevfîk Bey-Devr Gazetesi-Midhat PaşaSultan Aż̂z- Hacopulo Çarşısı

Mu'allim Nâci'nin gazelseralığı birçok kimseleri rencide hâtır etmeye başlamıştı. Midhat Efendi bihakkın münfail oldu; damadını, Şeyh Vasfi'yi ve bunların a'vanını Tercümân-1 Hakîkat'ten ib'âd eyledi. Yârân-1 basafa heyet-i mecmua ile Saadet gazetesine nakl-1 mekân ve kalem ettiler. Saadet de neşriyât-1 rindâne devâm eyledi.

Nâci'nin gazelsera, meyhânesi ... edeb olanlardan Mustafa Reşîd Bey’dir. Mustafa Reşîd Bey matbu'ât-1 Osmâniyyenin kadim bir siması, saf ve latifdir. Sultan-1 üdebâ Abdülhak Hâmid Bey şeyhü'l muharririn ise Mustafa Reşîd Bey’dir.

Mustafa Reşî̉ Bey birçok romanlar, şunlar bunlardan mâada kırk sene evvel Şark Mecmuası'nı, andan iki sene sonrada (enveran zekâ) mevkûtesini te'sis ederek alem-i neşriyâta hizmetler etmiştir. En sade ve en kısa cümleler yazmakta hâ'iz kasbü'l sebakdır. Hele sade ve ruh nevâz şarkıları sehl-i mümteni'dir. Şâire-i şehire Nigâr Hanım merhûme:

-şu saf ve sade Mustafa Reşîd şu delnevaz şarkıları bu kadar selis, bu kadar zarîf ve bedii’ 
olarak nasil yazar?!

Deyu izhar-1 beht ve hayret eder idi. Hakîkaten Mustafa Reşîd Bey Tasvîr-i hissiyat ve tabiatta tabiiliğin tabiiliğini firçalamış bir kalemdir. Bu hal Mustafa Reşîd'e bir muhebbe-i mahsûsadır.

Nâci'nin:

Bayramda bir nizamına koydum ki hânemi

Yaran görünce beri ki meyhâne sandılar

ve:

Evvel kader çakdım ki tersâzâdegânın aşkına

Barka döndüm neşr-i envar eyledim meyhânede

Beyitleri Mustafa Reşî̀ Bey'in pek sinirine dokunmuş idi. Mithad Efendi Nâci ve a'vânını Tercümân'dan ib'âd ve ib'âdını i'lan edince Reşîd Bey zabt-ı hissiyât ve infiâ'lât edemedi. Midhat Efendi'ye bir mektûb yazdı. ....ve meyhâne peralık devrine hatime verdiği için arz ve tebrîkât ve şükrân eyledi. Mithad Efendi bu mektûbu bir hamiş ile Nâci’ye gönderdi. İște bak!

Mustafa Reşîd Bey bile artık bu neşriyâta tahammül edemiyor. Tercümân-1 Hakîkati azl-1 nuvisân ve meyhâne peristândan tahliye ettiğim için beni tebrîk ediyor dedi. Nâci Reşî̀ Bey'in mektûbundan münfail ve muğber oldu. Saadet de şu kıt'ayı-sadece- neşr ederek Reşî̉ Bey’i tehdid eyledi:

Olacaktır işin fenâ çalı.

Haddin elbette sonra bildirilir.

Olacaktır işin fenâ ne demek?

Orasını Mustafa Reşîd bilir.

Sırrı Paşa (Giridi) Trabzon' da vali idi. İstanbul Postanesi geldiği zaman ta’âmda idi. Bâlâdaki k1t'ayı görünce irticalen:

Ne ma'lûm ne müstefid bilir

Orasını Hazret-i Reşîd bilir

Takdîratını ibzal eyledi. Nâci'nin kıt'ası ve Sırrı Paşa'nın mukâbelesi şayia' oldu. Hâfıza-i en'âma tevdi' ederek tenvî'-i suhana hizmeti de inkâr edilmez.

Bir sürüçin atın başı kesilmez

deriz. Bir mu’allim Alitebar daha 298 senesi Mekteb-i Terakki mu'allimliğinde iken:

Enbiyâ gerçi hata etmemiş ama ümmet

Hâ'iz-i rütbe-i peygamber-i zişan olmaz

demişdir.

Ahmed Midhat Efendi 1288 senesi Ağustos'unun on yedinci pencşembe günü (devr) gazetesini neşr etti. (Devr) yalnız bir nüsha neşredilebildi. Derhâl ta'tîl edildi. Ta'tîl Cuma gününe 
tesâdüf etmiş idi. Cuma gününde gazete ta’tîl olunur mu ya? diyerek halk bir hayli söylendi. Hele Ebuzziya Tevfîk pek müteessir oldu. 1290 senesinde neşr ettiği Sâlnâme-i Hadikada bundan teessür ve telehhüfle bahseder. Devr'in ilk nüshası İstanbul halkı ezhân-1 umumiyesinde büyük bir te'sîr yapmış idi. Midhat Efendi Devr'in (silinmiş) nüshasını Ala Rochfort yazmış (silinmiş) Midhat Paşa'ya -dehşetli- bir açık mektûb ile hitâb etmiş idi. Maksadı Midhat Paşa'ya hücum mu idi? Yoksa Midhat Paşa'ya hücum kisvesi altında Sultan Azîz'e mi taarruz etmek istiyor idi? Anlayamadım. O açık mektûbun bilmem ki bu gün bile bir sûretini neşr etmek mümkün olur mu?

Devr gazetesi Beyoğlu'nda Hacopulo çarşısında 13 numarada tab' ve neşr olunmuştur. Kemâl Bey'in İbret gazetesi de bu çarşıda neşr edildiğini akdemce yazmış idim. Hacopulu Çarşısı'nın eskileri bulunup da İbret muharrirlerinin ictima' ettikleri (terasa) mahalli ve Ahmed Midhat Efendi'nin 13 numerulu matba'a ve idârehânesi mevkii' ta'yin etse insan atiye-i edeb için bir ziyâretgah elde etmiş olur.

Devr'in tek nüshasını istinaf-1 hukûk zabit kâtiplerinden İbrahim Fahreddin Bey Nâmık'ul hurûfa hediye eyledi. Nâmık'ul hurûfun da liecli'l hıfz mevze-i hümayuna gönderecektir. İbrahim Fahreddin Bey’e arz-1 şükran ederim. Kıymetli bir yadigâr-1 millî ihsan ettiler.

\section{MATBU'ÂT-I OSMÂNIYY HÂTIRALARI ${ }^{24}$}

Resmî olmağla beraber birinci gazetesi olan Takvîm-i Vekâyi' 1247 târîhinde te'sis olundu. Bunun için ayrıca bir matba'a te'sis olundu. Matba'a binâsı Beyazıd'da Bab-1 Seraskerî ile Maliye Nezâreti arasındaki caddenin sol tarafındadır. Üzerinde kitâbesi de vardır.

Mermer güzel bir binâdır.

Takvîm-i Vekâyi' gazetesini çıkarmak kimin rey ve iktirah-1 eseri olduğunu Sultanzâde Selahaddin Bey haber veriyor ve Takvîm-i Vekâyi’nin neşri Reşîd Paşa'nın kaleminden çıkma bulunduğunu söylüyor.

Gazetenin mukaddemesinde ise keyfiyet-i neşrin ricali ve vükela-yı devletçe düşünülmüş olduğu yazılmıştır. İsim zikr olunmamıştır. Devair-i devletten her gün cereyân eden vakâyi’ için birer muhtıra yazılır, Takvîm-i Vakâyi' nezâretine gönderiliyor idi. İlk nazar ve vakanüvis Esa'd Efendi ta'yin olunmuştur. Bu zât şehzâde demekle ma'rûftur. Rütbesi Kâdıasker idi. Ayrıca bir binâ inşâ ve bir matba'a te'sis etmek, bir Kâdıaskeri nazır ta'yin etmek Takvîm-i Vakâyi' devletin atf ettiği ehemmiyet ve kıymeti gösterir. Sultan Mahmûd-u Sâni âsarından istidlal olunduğu üzere, kariha sahibi büyük bir padişah idi. Fakat Takvîm-i Vakâyi' te'sisinde büyük bir rol oynamamış olmalıdır ki gazetesinin mukaddemesinde bahs olunmayub bil'akis vükelâ ve ricâl devletçe muktas addolunduğundan bahs olunmuştur.

Takvîm nazırından gayri olarak da iki kâtib umur-u tahrîriye me'mur edilmiş idi. Vakanüvis Lütfî Edendi, 1262 târîhinde takvim kitâbetine nakl ma'muriyet etti. O zaman zabtiye meclisi baş kâtibi idi. Tarik-i kelemiye geçmiş idi. 1280 târîhine kadar Lütfi Efendi Takvîm kâtibliğinde bulundu. Bu zât Boyacı Köyü'nde ikâmet eder idi. 1302,1303 senelerinde bu zatı ekseriyetle vapurda tesâdüf eder idim. O zaman tekrâr tarik-i ilmiye geçmiş, Kâdıasker olmuş idi. Cebe ve festâr ile gezinir, uzun boylu, hoş sözlü, bezlegû bir zât idi. Yalısı vapur iskelesinden çıkılıb sola 
doğru gidildikde ikinci yalı idi. Birinci yalı Neş'e Bey merhûmun yalısı idi. Bu zât da zarafâdan idi. Hoş sözlülük, latife perdarlık, atub tutma bu zatta yetmiş idi. Eski büyük hanedanlığını temsil eder idi. Kapısı açık, mâidesi ammeye şamil idi. Ya rab! 1301-1311 istanbul'u ne İstanbul idi?.. o letafet-i hayat, o ulviyet-i hısâl acaba ne oldu?... bu kadar az zamanda bu kadar büyük tahvilât ve zâti'ât nedir?

1262 senesinde Lütfi Efendi ile beraber Râmiz Paşazâde İzzet Bey dahi takvim kâtibliğine alındı. Mütercim olarak da Alko Bey, İstifnaki ve Kostaki Bey Adosyidis dahi ma'mur edildi. Bu zevâtdan yalnız Kostaki Bey’i tanıdım. Bu zât Sisam Beyliğini ihrâz etti ve vezir oldu.

\section{Necib Âsım Bey Efendi'ye}

Diyojen muharriri Ali Bey'in pederi Yusûf Cemîl Efendi hakkında Ziyâ Paşa'nın bir vasfiyesi dahi vardır. Anadolu Hisârı iskelesinden sola doğru bir hayli ilerledikten sonra yol, dağa sapar ve her iki tarafı selvî ağaçlarından tarh olunmuş hıyâbân başlar. (Tasvîrim 1301 senesi Temmuz'unda gördüğüm hal ve şâna ma'tuftur. Hal-i hazırını bilmem.) Bu hıyâbân bir hayli i’vicâclardan sonra zirveye vâsıl olur ki müntehasında harem ve selamlık olmak üzere iki ayrı da'ireden mürekkeb Yusûf Cemîl Efendi Köşkü gelir. Bu köşkün dağ tarafında bir araba yolu vardır ki Sultan Aziz devrinde Üsküdar ve Çamlıca'da sakil ricâl ve Çubuklu ve Beykoz'da mukim vükelâ bu kapıdan arabalarla köşke gelirler zevk-ü sefa eylerler imiş deyu o zamana yetişmiş ehl-i sefa rivâyet ederler idi.

Devr-i Azîz'i evâhirinde başlayub devr-i Hamîd evâi'line kadar devâm edebilmiş olması zan olunan mizah gazetelerinden hatırlayabildiğim dört dane dergi Diyojen, Hayâl, Çâylâk, Çıngıraklı Tatar'dan ibarettir. Hayâl bir hafta gayet dinç bir pehlivanın bir sahifelik resmini yapdı. Pehlivanı zencirlere bağladı altına da:

Matbu'ât kanun da'iresinde serbesttir.

İbaresini yazdı. Hayâl kapadıldı ve sahibi olan Teodor Kasab mehterhâneye sevk edildi. Nâmık Kemâl Bey'in tevkîf ve teb'idi de bu zamana müsâdiftir deyu Nâzım Paşa rivâyet eder.

\section{MATBU'ÂT-I OSMÂNIYY HÂTIRALARI ${ }^{25}$}

Matbu'ât-1 Osmâniye târîhi yazılırken ta'rif ve tasvîre sezâ bahs ve devirlerden beri de kable'ttab' tedkîk ve mu'âyene usulü devridir. Ceraid-i yevmiye için Hâriciye Nezâreti'nde matbu'ât-1 hâriciye ve matbu'ât-1 dâhiliye unvânıyla bir iki kalem odası var idi.

Kitapşar için de ma'ârif nezâretine mürâcaat olunurdu. Şimdiki ma'ârif nezâretinin bir odası encümen-i teftîş ve muayeneye tahsîs olunmuş idi. Bu odanın zihniyetini yine o odanın a'zâ-yı müdavemesinden Tarsuslu Hoca Hayret Efendi irice bir kitâb zanneyleyib [karai’ni çizmişler] misra'yyla tasvîr ve tabir eylemişdir.

F1kh-1 İslâm'a müteallik olan eserle bu encümenden mâada bir de (tedkîk-i müellifât-1 şeri'yye) unvânıyla Bab-1 Meşihatta müteşekkil bir heyet de mu'âyene ve teftîş olunur idi. Bu heyetin işlerinden bir danesini nakl edeyim.

Evâ̂l-i devr-i Hamîdî de Hâriciye Nezâreti’ni, Mekteb-i Sultanî müdüriyetini işgal etmiş̧ 
olan ve bir müddet Girit valiliğinde dahi bulunan Savâ Paşa ulûm-u İslâmiyeye pek meraklı idi. Ehl-i İslâm'a da pek çok hürmet eder idi. Girit Valiliğinde bulunduğu zaman her akşam meclisine ulema-yı İslâmiyeyi davet eder, onlar ile muhavere ve münazaradan pek ziyâde zevkiyab olur idi. Bu zât evasit-1 devr-i Hamîdî de Paris'e çekildi ve orada Hukûk-u İslâmda Usul (Methode du Droit Musulmane) unvânıyla iki ciltlik bir eser neşr eyledi.

Savâ Paşa, Fuad Paşa gibi tabib olarak yetiştiği halde icra-yı tebabet etmemiş, meslek-i siyâsiyâta, diplomatlığa salık olmuş idi. Hâriciye Nezâreti'ni ihrâz ve idâre etmiş bir vezir idi. Me'muriyet hizmetlerinden biri de Mekteb-i Sultâni müdüriyetidir. Bu zât Mekteb-i Sultâni müdüriyetinde bulunduğu zaman orada bir de Mekteb-i Hukûk te'sis etti ve Mekteb-i Sultâni'nin diğer dersleri gibi hukûkun bazı aksamını Fransızca okutturdu. Fakat Mekteb-i Hukûk te'sis etmekle kalmayarak kendisi de Hukûk-u İslâmiyeyi ta'mîke koyuldu. Elhak iki eser Meydâna getirdi. Târîh-i Adliye-i İslâmî yazıldık da Savâ Paşa'nın namı tebcili ve ta'azzüm ile zikr ve irâd edilmemek mümkün değildir. Bu eserlerin birincisi muhâkeme-i şer'iyye-i Osmâniyenin vech-i teşkîline dairdir. Yani Teşkîlât-1 Muhâkeme-i Şer'iyye-i Osmâniye'dir. Diğeri de bâlâda ismi geçen Usul-u Fıkh-1 İslâm'dır. Savâ Paşa te'ehhül etmemiş idi. Yegâne zevkî okumak, yazmak, eser vücuda getirmek ve adam yetiştirmek idi. Bu iki eserinden başka biri de (Kânunnâme-i Âli Osman) tekvin ve tercümesi olmak lâzım gelir ki elde etmek ve görmek fakire nasîb olmamıştır.

Savâ Paşa an aslı Yanyalı idi. Bir hemşiresi var idi ki Edirne Vali mu'âvini Pâpâdopulos Efendi'ye tezvic edilmiş idi. Hemşire zâdesi olan hanımda İskender Hoca Efendi'ye tenkih edilmiştir. Hoca Efendi bu sûretle Savâ Paşa’ya damat olmuşdur. Bu zât dahi öyle bir kütüphâne vücuda getirmiş idi ki târîh-i Osmanî için bir hazine, bulunmaz bir define idi. Büyükada da Bahçivan oğullarından satın alınan hâneye ayrıca bir kârgîr da'ire yapılarak kütüphâne ittihaz olunmuş idi.

İskender Hoca Efendi’nin vefatından sonra Berlin İmparatorluk Kütüphânesi el altından bu kütüphâneyi iştirâ etmiş, Almanya sefaretine nakl ettirmiş, fakat mütarekenin araya girmesi üzerine Berlin'e sevke kadir olamayarak nihâyet Flemenk sefareti vasıtasıla evvelki sene muamele-i nakliye dahi yapılmıştır.

Savâ Paşa kiliseler meselesinde ve İsmet Paşazâde Rıza Paşa'nın adliye nezâretinde devlete darladı, Paris'e çekildi. Növiyide bir hâne isticar ederek ahir ömrünü orada geçirdi. Kütüphânesini dahi Paris'e nakl etmiş idi. Bade'l vefat kütüphânesini katib-i husûsiyesi bulunan bir Fransı'a vasiyet etmiş, kitaplar ve bi'l cümle evrak ve muharriratı o katibte kalmıştır. 1910-1911 Paris seyahati mahdudumda bu kâtibi ve Savâ Paşa kitaplarını çok aramış isem de bulamadım. Bu kütüphânede târîh-i Osmâninin birçok cihetlerini tenvîr edecek âsâr ve muharrirat bulunduğuna kaniim. Fakat o zaman hasbe'l meslek en çok alakadar olduğum cihet Savâ Paşa'nın âsâr-1 İslâmiyesini tahrîrde esası olan kitapları ve bu kitaplardan istihraç ettiği kuyudat idi.

Savâ Paşa (Usul-ü Fıkh-1 İslâm) 1 Mu'allimi Edirne müftüsü Nuri Efendi'nin himmet ve delâletiyle tahrîr ve tertib ettiğini söyler. Bu eserin birinci cildini tercüme ederek ruhsat istihsal etmek üzere Ma'ârif Nezâreti'ne takdim etmiş idim. Encümen-i teftîş ve muayenece uzun uzadı tedkîkden sonra Bab-1 Meşihata gönderildi. Ulemadan Halis Efendi merhûmun riyaset ettiği (Tedkîk-i Müellifât-1 Şer'iyye) meclisine havale olundu. Halis Efendi halis'ül kalb bir zât idi. İsmet Paşazâde Rıza Paşa gibi istikâmet ile ma'rûf bir vezirin sıhhıyetine dâhil olabilmesi - o zamanın hükmünce- fezâ'il-i ahlakiyesinin bir hanı idi. Bu münasebetle ben ümid etdim ki Halis Efendi çaresini bulacak ve kitâbın neşrine ruhsat verebilecektir. Bir buçuk sene tedkîkat ve takibatdan 
sonra bir gün Halis Efendi dedi ki:

- Oğlum, bu kitâbın nakilleri nerede? Nakillerini görmedikçe kitâb-1 fikhiyedeki mahallerini bulmadıkça ben bu kitâbın neşrine nasıl müsa'ade verebilirim?

Senelerce sarf ettiğim emek ve beslediğim ümid bir lahzada mahv ve hebâ oldu. Savâ Paşa'y1 nerede bulmalı? Nuri Efendi'yi nerede ele geçirmeli? Hangi zamanı bu işe hasr ve tahsîs etmeli? O zaman Paris'e mektûb yazmak, Savâ Paşa ile muhabere etmek tehlikesiz bir iş değildi. Haydi o da göze aldırılsın uğraşmaya maddeten vakit yok idi.

Bad'e ba'den İzzet Holo Bey (İzzet Paşa) mabeyn-i hümayuna ikinci ve'l ahire birinci kâtip oldu. İzzet Bey Mısırlı Kadrî Paşa'nın “El'hükema'ül neşr'iye fi'l ahvâl-i Şâhsiye” nam eserini Türkçeye tercüme etmiş idi. Fetvâhâne bu eserin dahi neşrine müsa'ade etmedi.

\section{Kaynakça}

Abdurrahman Âdil, "Matbu'ât-1 Osmâniye Hâtıraları", İkdâm, 1 Cemaziyulahir 1340, Nu: 8936, s. 4.

Abdurrahman Âdil, "Matbu'ât-1 Osmâniye Hâtıraları", İkdâm, 10 Rebiyül-evvel 1340, Nu: 8857, s. 2.

Abdurrahman Âdil, “Matbu'ât-1 Osmâniye Hâtıraları”, İkdâm, 13 Receb 1340, Nu: 8975, s. 3.

Abdurrahman Âdil, "Matbu'ât-1 Osmâniye Hâtıraları”, İkdâm, 15 Şa'bân 1340, Nu: 9007, s. 3.

Abdurrahman Âdil, "Matbu'ât-1 Osmâniye Hâtıraları", İkdâm, 18 Rebiyül-evvel 1340, Nu: 8864, s. 4.

Abdurrahman Âdil, "Matbu'ât-1 Osmâniye Hâtıraları", İkdâm, 25 Rebiyül-evvel 1340, Nu: 8871, s. 2.

Abdurrahman Âdil, "Matbu'ât-1 Osmâniye Hâtıraları", İkdâm, 3 Rebiyül-ahir 1340, Nu: 8878, s. 2.

Abdurrahman Âdil, "Matbu'ât-1 Osmâniye Hâtıraları", İkdâm, 6 Cemaziyülevvel 1340, $\mathrm{Nu}: 8911$, s. 4.

Birinci A., "Hatırat Türündeki Kaynakların Tarihi Araştırmalardaki Yeri ve Değeri”, Atatürk Araştırma Merkezi Dergisi, Sayı: 41, 1998, s. 611- 620.

Caesar G. I., Gallia Savaşı, Çev. Furkan Akderin, Alfa Yayınları, İstanbul 2006.

Halil Halid, Bir Türkün Ruznamesi, Klasik Yayınları, İstanbul 2008.

Halil Sami, "Rusya Hâtırâtımdan -I", Tearüf-i Müslimin, 1/10, s.164-166.

Halil Sami, "Rusya Hâtırâtımdan -II", Tearüf-i Müslimin, 1/12, s.195-197.

Halil Sami, "Rusya Hâtırâtımdan -III", Tearüf-i Müslimin, 1/14, s.229-231.

Kara, H., "İkdamcı Cevdet'in İsviçre Notları Işı̆ğında Osmanlı Aydınının Batı Algısı", History Studies İnternational Journal Of History, 10/7, 2018, s.163-184. 
Kütükoğlu, M., Tarih Araştırmalarında Usul, Elif Kitabevi, İstanbul 2007.

Okay, M. O., "Hatırat”, Diyanet İslam Ansiklopedisi, C. 16, İstanbul 1997, s. 445-449.

Sâmi Pâşâzâde Sezai, "İsviçre Hâtırâtı”, Edebiyat-1 Umumiye Mecmuası, 1/14, s. 241-244.

Sâmi Pâşâzâde Sezai, "İsviçre Hâtırâtı", Edebiyat-1 Umumiye Mecmuası, 1/15, s. 257-258.

Talât Paşa'nın Anıları, Yay. Haz. Alpay Kabacalı, Türkiye İş Bankası Kültür Yayınları, İstanbul 2000.

Togan, Z. V., Tarihte Usul, Enderun Kitabevi, İstanbul1985.

Turan A., “Abdurrahman Âdil Eren'in (1868-1942) Hayatı, Eserleri ve Mahkeme-i Temyiz Adlı Eserinin Tahlili”, Türk Hukuk Tarihi Araştırmaları, 23, 2017, s. 57-80.

Yalçın, H. C., Edebiyat Anıları, Basıma Haz., Rauf Mutluay, Türkiye İş Bankası Kültür Yayınları, İstanbul 1975. 